\title{
PERAN ORANG TUA TUNGGAL (IBU) DALAM MENGEMBANGKAN \\ MORALITAS ANAK DI KELURAHAN TLOGO MULYO KECAMATAN PEDURUNGAN SEMARANG
}

\author{
Nurdiana \\ dieanagrace@gmail.com. \\ Prodi Pendidikan Pancasila dan Kewarganegaraan \\ Universitas Jabal Ghafur
}

\begin{abstract}
Abstrak
Keutuhan sebuah keluarga (ayah, ibu, anak) merupakan salah satu faktor dalam menguatkan moral anak, hal ini akan berbeda bila keluarga tidak utuh atau single parent, dalam hal ini bagi orang tua tunggal (ibu) dalam mengembangkan moralitas anak. Penelitian ini bertujuan untuk menganalisis bagaimana bentuk keluarga fungsional dari orang tua tunggal (ibu), Menganalisis hasil dari penanaman pengetahuan moral, perasaan moral, dan mewujudkan tindakan moral bagi anak yang memiliki orang tua tunggal(ibu) dalam mengembangkan moralitas anak. Metode penelitian yang digunakan metode kualitatif. Hasil penelitian menunjukkan meskipun orang tua tunggal (ibu)memiliki kesibukan dalam mencari nafkah akan tetapi orang tua tunggal (ibu) bisa membagi waktunya dalam membimbing,memantau dan mengarahkan tumbuh kembang anak dan mampu memberikan putra-putrinya pendidikan formal,informal dan nonformal. Orang tua tunggal (ibu) bisa menanamkan pengetahuan moral, perasaan moral dan mewujudkan tindakan moral bagi anak-anaknya.
\end{abstract}

Kata kunci: Single Parent, Moralitas Anak

\section{PENDAHULUAN}

Moral bagi anak-anak tumbuh berhubungan dengan lingkungan sosial budaya sebagai tempat individu bergabung, dan akibat seseorang menjadi anggota kelompok. Ketika masyarakat berpikir bahwa moralitas adalah sesuatu yang terus mengalami perubahan relatif secara individu, tergantung pada situasi dan tergantung ada diri sendiri De Vitis (2013).

Kenakalan remaja yang disebabkan karena broken home (perceraian) dapat diatasi atau ditanggulangi dengan cara-cara tertentu, seperti tanggung jawabnya orang tua dalam memelihara anak-anaknya seharusnya mampu memberikan kasih sayang sepenuhnya, sehingga anak tersebut merasa seolah-olah tidak pernah kehilangan ayah atau ibunya. Di samping itu keperluan anak secara jasmaniah (makan, minum, pakaian, dan sarana-sarana lainnya) harus dipenuhi pula sebagaimana layaknya sehingga anak tersebut terhindar dari perbuatan yang melawan hukum misalnya, pencurian, penggelapan, penipuan, gelandangan, dan penyalahgunaan obat-obat terlarang. Ketika moral anak sudah jatuh maka akan sulit untuk mengembalikan menjadi anak baik (Sudarsono,1995:126).

Pada dasarnya Moral yang diajarkan pada anak karena anak akan secara alami menyerap apa yang dilakukan orang tua. Pendidikan moral dikatakan pendidikan non formal tetapi akan sangat membekas pada diri anak maka sangat sulit ketika orang tua harus mendidik anak sendirian, moralitas orang tua dalam keluarga itu menjadi salah satu contoh pendidikan karena memaksa 
orang tua tunggal (ibu) tersebut harus berperan ganda dalam keluarga dan anak.

Diambang pintu kedewasaan menanti tugas-tugas yang harus mereka penuhi, maka bekal-bekal tertentu sangat perlu dipersiapkan bagi mereka. Suatu fakta didalam sejarah perkembangan umat memelihara kelangsungan hidupnya untuk senantiasa menyerahkan mempercayakan hidupnya ditangan generasi yang lebih muda Surakhmad (2009).

\begin{tabular}{lccr}
\multicolumn{2}{c}{ Perempuan yang } & bekerja & yang \\
menyandang & banyak & beban & akan \\
berimplikasi & terhadap & segala & aspek
\end{tabular}
kehidupannya. Sudah pasti ketika dia bekerja akan ada pergeseran -pergeseran peran dalam kehidupan rumah tangganya. Dari seorang perempuan yang dianggap selalu berada di rumah tiba-tiba harus keluar rumah bekerja, tentu ada situasi yang memerlukan diskusi lebih jauh. Pengaruh sebagai perempuan berpenghasilan tersendiri juga perlu pemahaman yang menyeluruh, karena dibanyak kasus ternyata kemampuan ekonomi yang dimiliki oleh perempuan tidak secara langsung menaikkan tawar menawar meraka dalam keluarga dan dalam masyarakat (Astuti,2000) anak-anak menjadi nakal atau manja.

Menurut Robert J. Havighurst (Saleh, 2005), moral yang bersumber dari adanya suatu tata nilai yakni a value is an object estate or affair wich is desired (suatu obyek rohani atas suatu keadaan yang di inginkan). Maka kondisi atau potensi internal kejiwaan seseorang untuk dapat melakukan hal-hal yang baik, sesuai dengan nilai-nilai value yang diinginkan itu (Sholeh, 2005:104).

Pada sisi yang lain kenakalan remaja sering terjadi karena perceraian orang tua atau orang tuanya meninggal karena disebabkan tidak intensnya salah satu orang tua membuat anak merasa hidupnya tidak normal seperti anak-anak lain. Kondisi semacam ini membuat anak tersebut kurang percaya pada orang tua dan selalu mencari jalan keluar setiap ada masalahsendiri, bisa jadi mereka terlibat dalam pergaulan yang tidak sepantasnya (buruk). Karena itu akan terjadi tergesernya nilai-nilai moral pada anak dan akan terjadi perbedaan proses perkembangan moral pada anak dalam korban perceraian.

Kenakalan remaja yang disebabkan karena broken home (perceraian) dapat diatasi atau ditanggulangi dengan cara-cara tertentu, seperti tanggung jawabnya orang tua dalam memelihara anak-anaknya seharusnya mampu memberikan kasih sayang sepenuhnya, sehingga anak tersebut merasa seolah-olah tidak pernah kehilangan ayah atau ibunya. Di samping itu keperluan anak secara jasmaniah (makan, minum, pakaian, dan sarana-sarana lainnya) harus dipenuhi pula sebagaimana layaknya sehingga anak tersebut terhindar dari perbuatan yang melawan hukum misalnya, pencurian, penggelapan, penipuan, gelandangan, dan penyalahgunaan obat-obat terlarang. Ketika moral anak sudah jatuh maka akan sulit untuk mengembalikan menjadi anak baik (Sudarsono,1995:126).

Kegagalan dalam proses pemenuhan kebutuhan tersebut akan berdampak negative pada pertumbuhan fisik dan perkembangan intelektual, mental, dan sosial anak. Anak bukan saja akan mengalami kerentanan fisik akibat gizi dan kualitas kesehatan yang buruk, melainkan pula mengalami hambatan mental, lemah daya nalar dan bahkan perilaku-perilaku maladaptive, seperti : autism, 'nakal', sukar diatur, yang kelak mendorong mereka menjadi manusia 'tidak normal' dan perilaku kriminal (Huraerah, 2006: 27)

Analisis dalam penelitian ini mengacu pada teori bahwa masyarakat merupakan suatu sistem sosial yang terdiri atas bagianbagian atau elemen yang saling berkaitan dan saling menyatu dalam keseimbangan. Masyarakat terdiri dari kumpulan individuindividu membentuk kelompok sosial, organisasi, dan lembaga institusi tiada lain yaitu untuk mencapai keseimbangan sosial. 
Teori fungsionalisme struktural Robert King Merton adalah menekankan kepada keteraturan (order) dan mengabaikan konflik dan perubahan-perubahan dalam masyarakat. Konsep utamanya adalah fungsi, disfungsi, fungsi laten, fungsi manifes dan keseimbangan (equiliberium).

Berdasarkan fakta-fakta yang telah dipaparkan, maka penelitian ini bertujuan untuk menganalisis bagaimana bentuk keluarga fungsional dari orang tua tunggal (ibu), Menganalisis hasil dari penanaman pengetahuan moral, perasaan moral, dan mewujudkan tindakan moral bagi anak yang memiliki orang tua tunggal (ibu) dalam mengembangkan moralitas anak.

\section{METODE PENELITIAN}

Penelitian ini menggunakan pendekatan kualitatif. Penelitian dilaku-kan di Kelurahan Tlogo Mulyo. Sumber data utama dalam penelitian ini yaitu hasil wawancara dengan 6 orang orang tua tunggal (ibu) sebagai informan utama dan kenyataan yang dialami di lapangan, seperti perilaku sehari-hari antara orang tua tunggal dan anak juga masyarakat. Fokus penelitian ini adalah melihat hasil dari penanaman pengetahuan moral, perasaan moral dan mewujudkan tindakan moral bagi anak yang ditanamkan oleh ibu dalam keluarga single parent. Oleh karena itu apa yang digali dan apa yang dipotret meliputi bentuk keluarga fungsional dari orang tua tunggal (ibu) dan bentuk hasil penanaman pengetahuan moral, perasaan moral, dan mewujudkan tindakan moral bagi anak yang memiliki orang tua tunggal.

Penelitian mengambil lokasi di Kelurahan Tlogo Mulyo. Pengambilan Kelurahan Tlogo Mulyo sebagai lokasi penelitian karena kehidupan single parent menjadi salah satu tolak ukur yang cukup banyak di Kelurahan Tlogo Mulyo dibandingkan dengan daerah lain di Kecamatan Pedurungan yang nota-benenya merupakan tempat peralihan antara desa dan kota sehingga anak-anak harus benar-anak dalam pendidikan moral harus benar-benar diperhatikan. Teknik pengambilan informan dengan teknik snowball sampling. Penggunaan snowball sampling karena peneliti belum mengetahui siapa saja yang akan dijadi-kan informan karena penentuan informan dilakukan saat peneliti mulai memasuki lapangan dan selama penelitian berlang-sung. Informan dipilih berdasarkan pertimbangan dalam memberikan data atau informasi yang diperlukan sesuai dengan kebutuhan penelitian. Setelah melalui wawancara awal, peneliti dapat menetapkan informan lainnya untuk memberikan data lebih lengkap. Oleh karenanya dalam penelitian ini terdapat key person. Teknik pengumpulan data dilakukan melalui wawancara mendalam, observasi, dan studi dokumentasi.

\section{HASIL DAN PEMBAHASAN Pengetahuan Moral}

Ibu SN memiliki seorang putra yang masih bersekolah di SMK Pelita berinisial DDP. Dalam mendidik anaknya, sebagaimana yang didapati di dalam data wawancara, ibu SN tidak terlalu sering mengingatkan putranya ketika melakukan kesalahan. Namun, ibu SN selalu mengarahkan putranya untuk mengintrospeksi diri ketika melakukan kesalahan, serta memberitahu tentang apa saja yang tergolong dalam perilaku baik dan apa saja yang tergolong dalam perilaku buruk. Dalam mendidik ibu SN juga memberikan pendidikan kesadaran moral dengan menggunakan pendekatan keagamaan Pendekatan keagamaan ini biasanya berupa kedisiplinan dalam melaksanakan ibadah, seperti shalat dan mengaji.

Ibu SN juga memberikan contoh langsung kepada putranya. Sebagaimana dalam kutipan wawancara pada ibu SN yaitu "Saya selalu memberikan contoh yang baik agar anak saya bisa berperilaku yang baik". Dibenarkan juga oleh putranya yang 
mengatakan bahwa "ibu selalu memberikan contoh yang baik untuk saya"

Tabel 1. Tabel Peran Orang Tua Tunggal (Ibu) dalam mengembangkan Penge-tahuan Moral Anak

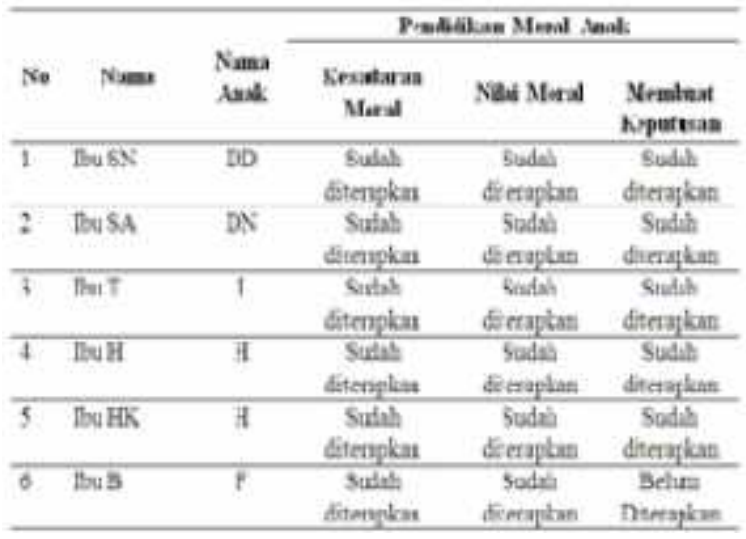

Sumber: Survei Lapangan (dibuat,2016)

\section{Perasaan Moral}

Ibu SA merupakan salah satu orang tua tunggal yang harus mendidik anaknya dengan sendirian.Walaupun ibu SA bekerja sebagai seorang cleaning service namun ibu SA tetap berusaha memberi-kan sesuatu yang baik untuk anaknya.Ibu SA selalu menasehati anaknya untuk selalu berbuat kebaikan, seperti memberikan solusi kepada temannya yang sedang ada masalah.

Berikut ini wawancara yang dilakukan oleh peneliti kepada ibu SA, yaitu:

“....Saya mengajarinya dan mengingatkan saling menghargai pendapat orang lain,saya kasih solusi kalau ada temannya yang sakit atau butuh bantuan kalu kamu mampu yakamu bantu teman kamu...."

Apa yang dikatakan oleh ibu SA, tentang cara didikan dan ajaran ibu SA kepada anaknya, sama dengan yang dikatakan oleh anaknya, yaitu sebagai berikut wawancara yang dilakukan oleh peneliti dengan anaknya ibu SA:

".....Saya tidak boleh iri sama orang lain saya harus bisa percaya diri dengan apa yang ada dalam diri saya dan inilah keadaan saya, tidak boleh dipotong pendapat orang lain dan saling menghargai pendapat orang lain. Saya mendengarkan cerita teman saya dan saya kasih solusi biar masalahnya selesai agar tidak ada masalah lagi dan saya ikut meraskan apa yang tman saya rasakan...."

Maka dapat dikatakan bahwa ibu SA sudah mengajarkan dan menanamkan perasaal moral berupa empati kepada anaknya.Sehingga anak dari ibu SA bisa menjadi orang yang selalu mempedulikan temannya, jika ada salah satu temannya membutuhkan bantuan.

Tabel 2. Peran Orang Tua Tunggal (Ibu) dalam mengembangkan Perasaan Moral Anak

\begin{tabular}{|c|c|c|c|c|c|}
\hline \multirow[b]{2}{*}{ No } & \multirow[b]{2}{*}{ Sans } & \multirow[b]{2}{*}{ Ses Anak } & \multicolumn{3}{|c|}{ Pensas Moral Aask } \\
\hline & & & $\begin{array}{l}\text { Yesyakal } \\
\text { Kebaican }\end{array}$ & Empati & $\begin{array}{c}\text { Konndaha } \\
\text { Hati }\end{array}$ \\
\hline 1 & Dis 5X & DD & $\begin{array}{c}\text { Sudis } \\
\text { diterafan }\end{array}$ & $\begin{array}{c}\text { Sodih } \\
\text { dieraykas }\end{array}$ & $\begin{array}{c}\text { iodal } \\
\text { dixraplas }\end{array}$ \\
\hline 2 & IeSA & DN & $\begin{array}{l}\text { Suds } \\
\text { crenapan }\end{array}$ & $\begin{array}{c}\text { 5scha } \\
\text { ditrarkas }\end{array}$ & $\begin{array}{c}\text { gadtd } \\
\text { dinerbis }\end{array}$ \\
\hline 3 & for & $t$ & $\begin{array}{l}\text { Sudis } \\
\text { dteraglan }\end{array}$ & $\begin{array}{l}\text { Beim } \\
\text { diteragkan }\end{array}$ & $\begin{array}{l}\text { idds } \\
\text { dixrapias }\end{array}$ \\
\hline 4 & $\mathrm{InAH}$ & H & $\begin{array}{c}\text { Sndila } \\
\text { diteragian }\end{array}$ & $\begin{array}{c}\text { Sulph } \\
\text { dierathos }\end{array}$ & $\begin{array}{l}\text { Sodel } \\
\text { direglas }\end{array}$ \\
\hline 5 & Tha HEk & H & $\begin{array}{l}\text { Sudid } \\
\text { diterafian }\end{array}$ & $\begin{array}{c}\text { Soshh } \\
\text { dieraykas }\end{array}$ & $\begin{array}{c}\text { 3etse } \\
\text { dikrepiats }\end{array}$ \\
\hline 6 & IneB & 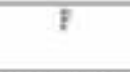 & $\begin{array}{l}\text { Sudb } \\
\text { tharelan }\end{array}$ & $\begin{array}{l}\text { Belum } \\
\text { dreratkas }\end{array}$ & $\begin{array}{c}\text { Beis } \\
\text { sencasus }\end{array}$ \\
\hline
\end{tabular}

\section{Tindakan Moral}

Tindakan moral seperti halnya D dan DN juga telah diberikan pendidikan terkait dengan nilai-nilai moral dan hal-hal yang dianggap baik di masyarakat oleh ibu T. Hal terpeting dari penerapan tentang pemahaman nilai-nilai moral adalah memahami mana saja hal-hal yang baik untuk dirinya dan berani mengambil keputusan jika mendekati hal-hal yang buruk. I merupakan salah satu anak dari orang tua tunggal yang berani mengambil keputusan terkait mana saja hal yang baik untuk dirinya dan mana hal yang harus dihindari karena tidak baik. I pun juga menyukai kebaikan, memilih teman yang benar akan membawa kebaikan juga untuk dirinya. Padahal dalam berteman, I diberikan kebebasan oleh ibu $\mathrm{T}$ tetapi dirinya mampu mengambil keputusan untuk membatasi mana teman yang baik menurutnya dan mana yang tidak. Seperti dalam petikan wawancara berikut ini: 
“....Kasih kebebasan tapi ada batasannya, kalau mendekati buruk ya dibatasin sama kemauan sendiri. Pinterpinter milih temen dan jangan bertemen dengan yang kurang baik. Pokoknya berperilaku baik terus...."

Dalam berteman selalu mempertimbangkan apakah baik berteman dengannya atau tidak. Jika temennya kurang baik atau mengarahkan ke hal yang tidak baik maka dia akan menjauh dan tidak lagi berteman dengannya. Jadi dalam bergaul di sekolah dan di masyarakat I selalu memilih teman mana yang mengajak kepada kebaikan. Karena pada dasarnya I menyukai kebaikan, oleh karena itu dalam penggalan terakhir wawancara dirinya mengatakan untuk selalu berperilaku baik.

$\mathrm{H}$ seperti yang telah dijelaskan pada sub-bab sebelumnya merupakan anak yang mempunyai pendirian, memiliki pemahaman tentang moral dan merealisasikannya dalam wujud tindakan-tindakan moral yang positif. Adanya sedikit perbedaan persepsi dan kekeliruan dalam pemahaman komunikasi antara $\mathrm{H}$ dengan ibu $\mathrm{HK}$, akan tetapi $\mathrm{H}$ tetap tergolong sebagai anak yang penurut. $\mathrm{H}$ berbeda dengan anak-anak yang lain yang seumuran dengannya. Kebanyakan anak belajar di malam hari sebelum tidur. $\mathrm{H}$ terbiasa bangun pagi hari pukul 03:00 untuk bangun belajar dan mempersiapkan keperluan untuk ke sekolah. Apa yang dilakukan $\mathrm{H}$ mungkin tidak lumrah, oleh karena itu adanya kekeliruan dalam pemahaman komunikasi antara $\mathrm{H}$ dan ibunya. Ibu HK baiknya memahami jika apa yang dipilih anaknya untuk membiasakan diri bangun pukul 03:00 merupakan sebuah kebiasaan yang baik. Lihat sisi baiknya, $\mathrm{H}$ akan banyak meluangkan waktu untuk mempersiapkan dan bisa membiasakan diri untuk shalat malam. Selain bisa melatih kepekaan terhadap pelajaran, bangun dini hari bisa melatih kepekaan $\mathrm{H}$ dalam beribadah kepada yang Maha Kuasa.
Apa yang dilakukan oleh $\mathrm{H}$ terdapat pada petikan wawancara kepada ibu HK berikut ini:

"..iyaa mengajarkan anak saya agar sopan santun dan saling menghargai. Harapan saya semoga anak saya bisa menjadi contoh yang baik bagi adik-adiknya. Saya memberi kebebasan dalam memilih teman asal masih dalam tahap kewajaran dan tidak melanggar norma-norma. Iya, tahunya ternyata anak saya belajar jam 3 malam. yaa begitu mbak kalau disuruh dia malah ga mau jadi dia terapkan disiplin diri sendiri..."

Berikut ini petikan wawancara kepada $\mathrm{H}$ putra ibu HK, berupa jawaban terhadap pernyataan dari ibu HK terkait belajar pada pukul 03:00:

"...ya begitu mbak saya kalau disuruh saya malah ga mau, jadi saya terapkan disiplin diri sendiri dan saya kalau belajar jam 3 malam mbak. Untuk bangun pagi dan saya sudah terbiasa bangun pagi cepat. Lalu berangkat sekolah.Ibu menegur saya dan menanyakan. Apa masalahnya sehingga saya tiba-tiba saja dimarahin ibu.."

Terlihat jika $\mathrm{H}$ seperti tidak menuruti kemauan ibunya, padahal dirinya menuruti kemauan ibunya untuk belajar. Hanya saja dia mempunyai waktu yang menurutnya lebih mudah untuk mengingat pelajaran serta membuat dirinya lebih bisa mempersiapkan diri untuk pergi ke sekolah. Pada petikan wawancara berikut ini akan dijelaskan tentang diri $\mathrm{H}$ yang menuruti kemauan ibunya:

"...ketika saya berada dalam suatu acara saya ikut membantu apa yang bisa saya bantuin di acara tersebut,ibu selalu mengingatkan agar saya berperilaku yang baik agar saya bisa jadi contoh yang baik bagi orang lain,ibu mengajarkan saya agar saya bisa mengendalikan diri dalam segala hal saya harus memperdalam ilmu agama..."

Apa yang coba ditunjukan oleh $\mathrm{H}$ sesuai dengan yang dikemukakan oleh Lickona (2103:87) terkait dengan kebiasaan baik yaitu kebiasaan adalah faktor 
pembentuk perilaku moral. Kebiasaan yang baik dibangun dengan banyak berlatih menjadi orang baik. Dengan artian seorang anak harus memiliki banyak pengalaman menolong orang lain, berbuat jujur, bersikap santun dan adil. Dengan demikian, kebiasaan baik ini akan selalu siap melayani mereka dalam keadaan sulit sekalipun.

Tabel 3. Peran Orang Tua Tunggal (Ibu) dalam membentuk Tindakan Moral Anak

\begin{tabular}{|c|c|c|c|c|c|}
\hline \multirow[b]{2}{*}{$\mathrm{x}$} & \multirow[b]{2}{*}{ Sama } & \multirow[b]{2}{*}{ Nama Anak } & \multicolumn{3}{|c|}{ Tiedslue Meril Anal } \\
\hline & & & $\begin{array}{c}\text { Kanpeterai } \\
\text { Iforal }\end{array}$ & Kellendak & Kebinasa \\
\hline 1 & fhats & DD & $\begin{array}{l}\text { Sudah } \\
\text { efergokan }\end{array}$ & $\begin{array}{l}\text { Solat } \\
\text { Siegoras }\end{array}$ & $\begin{array}{c}\text { Sodit } \\
\text { ditenation }\end{array}$ \\
\hline & for $\mathrm{K}$ & Ds & 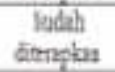 & $\begin{array}{l}\text { Solas } \\
\text { Eiterapias }\end{array}$ & $\begin{array}{l}\text { Sodita } \\
\text { Eitenation }\end{array}$ \\
\hline 3 & Ibe: & $t$ & $\begin{array}{l}\text { lodah } \\
\text { dinnolus }\end{array}$ & $\begin{array}{l}\text { 5odn } \\
\text { Eterapas }\end{array}$ & $\begin{array}{l}\text { Sodh } \\
\text { Etenglose }\end{array}$ \\
\hline & Ifolli & F & $\begin{array}{c}\text { badah } \\
\text { dientigas }\end{array}$ & $\begin{array}{l}\text { Sods } \\
\text { Eternogas }\end{array}$ & $\begin{array}{l}\text { Sodids } \\
\text { ditengation }\end{array}$ \\
\hline & Ibo荡 & F & $\begin{array}{l}\text { Jodah } \\
\text { èmengen }\end{array}$ & $\begin{array}{l}\text { Solda } \\
\text { Siteragías }\end{array}$ & $\begin{array}{c}\text { Sodh } \\
\text { diterasos }\end{array}$ \\
\hline & $\mathrm{IbeB}$ & F & $\begin{array}{l}\text { Jelumit } \\
\text { ernglan }\end{array}$ & $\begin{array}{l}\text { Beluin } \\
\text { Sierpan }\end{array}$ & $\begin{array}{c}\text { Bcluar } \\
\text { Diteration }\end{array}$ \\
\hline
\end{tabular}

\section{Implimentasi \\ Teori \\ Fungsional \\ Struktural \\ Pada \\ Penanaman \\ Pengetahuan Moral, Perasaan Moral dan Mewujudkan Tindakan moral Pada anak}

Berdasarkan temuan di lapangan, bentuk struktur keluarga orang Tua tunggal di Kelurahan Tlogomulyo, pada bentuk keluarga yang fungsional tentunya bersinerginya peran orang tua dalam memantau, membimbing, dan mengarahkan tumbuh kembang anak. Baik itu yang berhubungan dengan hal-hal yang bersifat jasmaniah maupun rohaniah (bathin). Bersinerginya peran orang tua, dalam hal ini Ayah dan Ibu bisa diwujudkan seperti melalui peran aktif Ayah dalam mencari nafkah untuk kebutuhan keluarga yang bersifat materil serta secara tegas dan berkelanjutan mengajarkan kepada anak tentang hal-hal apa saja yang dianggap baik, dan hal-hal apa saja yang dianggap buruk dalam lingkungan sekolah, masyarakat, negara, dan terutama dalam agama. Sedangkan Ibu di rumah membimbing anakanaknya dan mengarahkan kebiasaan anak ke arah kebaikan melalui pendekatan keagamaan dan kebudayaan setempat. Kemudian fungsi anak sebagai sebuah hasil untuk menciptakan situasi yang seimbang dalam struktur keluarga adalah belajar dan mematuhi dan menjalankan apa yang diperintahkan oleh orang tua. Ketika anak berkelakuan baik di masyarakat dan mematuhi keinginan orang tua, berarti keluarga tersebut dapat dikatakan sebagai keluarga yang fungsional. Karena masingmasing menjalankan fungsinya dengan baik, tentu kehidupan keluarga yang seimbang pun akan tercipta.

Bentuk disfungsional keluarga pada umumnya keluarga terdiri dari ayah, ibu, dan anak-anak. Ayah dan ibu berperan sebagai orang tua bagi anak-anaknya. Namun, dalam kehidupan nyata sering dijumpai keluarga dimana salah satu orang tuanya tidak ada lagi. Keadaan ini menimbulkan apa yang disebut dengan keluarga dengan single parent. Orang tua yang disebut dengan single parent adalah orangtua tunggal (ayah atau ibu saja). Ada banyak penyebab yang mengakibatkan peran orangtua yang tidak lengkap dalam sebuah rumah tangga menjadi tidak sempurna. Orang tua tunggal harus pandai membagi waktu, melengkapi statusnya sebagai ayah dan ibu sekaligus. Perannya sebagai ayah, sebagai pemimpin keluarga kecil yang dimilikinya. Kemandirian dalam mengambil keputusan dan membuat kebijakan secara mandiri untuk keluarga kecilnya.

Bentuk fungsi laten keluarga dapat terlihat melalui hasil pendidikan karakter yang didik oleh orang tua tunggal di Kelurahan Tlogo Mulyo . Adapun yang dilihat dari bentuk fungsi laten keluarga adalah hal-hal yang tidak diharapkan ketika sebuah keluarga masuk dalam fase disfungsi bertransisi untuk membentuk kembali menjadi sebuah keluarga fungsional. Adapun yang dilihat dari bentuk fungsi manifes keluarga adalah hal-hal yang diharapkan ketika sebuah keluarga masuk dalam fase disfungsi bertransisi untuk membentuk kembali menjadi sebuah 
keluarga fungsional. Hal-hal yang diharapkan ini dititikberatkan pada output yang dapat diperhatikan pada anak-anak dari orang tua tunggal. Tentu hal yang diharapkan yaitu anak tumbuh menjadi pribadi yang baik, menjadi anak yang penurut, menjadi anak-anak yang berprestasi, pintar dalam memilih pergaulan dan teman bermain yang baik, memiliki kedisiplinan dalam waktu, dan berperilaku baik di lingkungan masyarakat.

Mengacu pada teori Robert K. Merton Bahwa bentuk keluarga seimbang keadaan keluarga yang seimbang merupakan hasil akhir sebuah bentuk keluarga yang fungsional. Ketika dalam keadaan keluarga disfungsi di mana tidak adanya ayah yang berperan dalam mencari nafkah bagi keluarga. Sebuah keluarga dihadapkan dalam dua kemungkinan yaitu menjadi bentuk keluarga yang manifes (yang diharapkan) atau bentuk keluarga yang laten (yang tidak diharapkan). Setelah orang tua tunggal yang berhasil berperan ganda dan mendidik karakter anaknya dengan baik akan menciptakan sebuah bentuk keluarga yang seimbang yang setiap komponen dalam keluarga itu berperan sebagaimana mestinya. Orang tua tunggal (ibu) yang juga berperan sebagai ayah memenuhi fungsi dan perannya sebagai pendidik moral anak di rumah dan memenuhi kebutuhan jasmani anak-anaknya.Anak-anak punberperan sebagaimana mestinya, sebagai salah satu komponen dalam keluarga anak-anak mempunyai hak untuk mendapat kan pendidikan baik di sekolah ataupun di rumah serta pemenuhan atas kebutuhankebutuhan jasmaniah. Selain itu, anak-anak juga mempunyai kewajiban yaitu belajar dan menunjukkan bahwa dirinya berhasil mendapatkan pendidikan dengan menerapkan pendidikan karakternya di lingkungan sekolah, keluarga, dan masyarakat.

\section{SIMPULAN}

Meskipun orang tua tunggal (ibu) sibuk mencari nafkah akan tetapi orang tua tunggal (ibu) bisa membagi waktunya dalam membimbing, memantau dan mengarahkan tumbuh kembang anak dan juga mampu memberikan pendidikan formal, informal dan non formal untuk anak-anaknya sehinggaanak tumbuh menjadi pribadi yang baik, menjadi anak yang penurut, menjadi anak-anak yang berprestasi, pintar dalam memilih pergaulan dan teman bermain yang baik, memiliki kedisiplinan dalam waktu, dan berperilaku baik di lingkungan masyarakat. Orang tua tunggal (ibu) berhasil menciptakan kembali sebuah bentuk keluarga yang seimbang dengan berperan ganda terbukti berhasil.

Saran yang dapat diberikan, yaitu orang tua tunggal (ibu) terutama kerabat dekat dan khususnya ibu senantiasa memberikan kedekatan,kasih sayang, tegas dan menanamkan nilai-nilai agama dan nilai-nilai moral dalam masyarakat.Bagi anak belajar dan mematuhi kemudian menjalankan apa yang diperintahkan orang tua.

\section{DAFTAR PUSTAKA}

Astuti, Tri Marhaini Puji. 2011.Kontruksi Gender Dalam Realitas Sosial, Unnes Pres .

Cresswel, J. W. 2005. Pendekatan Kualitatif, kuantitatif, dan Mixed. Yogyakarta: Pustaka Belajar

Gunarsih, S. 1995. Psikologi Perkembangan Anak dan Remaja. Yogyakarta: Rake Sarasin

Huraerah, A. 2006. Kekerasan terhadap Anak. Bandung: Penerbit Nuansa

Lickona, T. 2013. " EducationFor Carracter". Bandung : Nusa Media

Meleong, L.2013.Metodelogi Penelitian Kualitatif.Bandung:PT Remaja.

Rachman, M. 2011.Metode Penelitian Pendidikan Moral Dalam Pendekatan KuantitatifKualitatif, campuran, tindakan, dan pengembangan. Semarang : Unnes Press 